\title{
THE EFFECT OF PEER REVIEW ON EFL STUDENTS' WRITING SKILL IN WRITING “NURSING CARE DOCUMENTATION"
}

\author{
Arina Hafadhotul Husna \\ Cendekia Utama Health College \\ arinahafadhotulhusna@gmail.com
}

\begin{abstract}
This study concerns on the effect of peer review on EFL students' writing skill in writing nursing care documentation. The aims of this study are to investigate the possible effectiveness of the peer review technique to increase the quality of nursing students' writing skill and to see whether this method motivates student to write. The method of the study is quantitative method. The participants were 78 nursing students in the fourth semester of Cendekia Utama Health College. They were randomly categorized into two experimental and control groups. In the experimental group were providing with an additional peer review instruction propossed by O'Muirheartaigh (1990). It includes the provision of constructive feedback to their peers and evaluating and correcting the peer's performances. They were paired for peer review, conferencing and exchanging their Nursing care documentation with those of their peers. The reviewers had to correct, evaluate and respond those Nursing care documentation. While, in the control group were traditionally handled by teacher who assigned them homework and correct their Nursing care documentation by themselves. The experiment was run over two months. The data were collected using questionnaire, pre - test and post - test for language proficiency and writing skill, peer response sheet, writing criteria and guidelines sheet.

The result of the study indicated that p-score is $0,000<0,05$, so that Ho is Rejected and $\mathrm{Ha}$ is Accepted. It means there is difference of Pre Test with Post Test score. It is known that statistic $t$ - arithmetic is -6.202 which means the score of pre - test is smaller than post - test with point score 6.202. It indicated that the writing of the students in the experimental group improved more than those in control group. Also, those engaged in peer review method were motivated to write more and enjoy writing. It was concluded that peer review provides learners with an authentic audience, increase the students' motivation for writing and enables them to receive different views on their writing.
\end{abstract}

Keywords: Peer Review, EFL Students, Writing Improvement, Nursing care documentation

\section{Introduction}

In the globalization era, English language plays an important role in improving students' knowledge and helps the students to gain success in every 
subject. It is not only as universal language but also as a tool to communicate in oral and written form to understand and figure out the information, mind, feeling, science, technology and culture. Therefore English language is one of the important subjects to be studied at school in Indonesia. Recently, English is a part of communication and it is also one of an important language to be mastered. There are four skills that have to be mastered in the English teaching and learning process, they are; listening, speaking, reading and writing which are integrated to achieve the Information level.

The students will be able to express their ideas in the written form if they have good skill in writing. So that writing is one of the important skills that should be mastered. However, Dempsey, Pytikzilling\& Burning, (2009); Gao(2007); O'Muicheartaigh, (1990); stated that writing skill is one of the four language skills (reading, speaking, listening and writing) that has been underestimated for a long time. While, Kim and kim (2005), suggested that students' writing have unproductive result and yields meaningless on the feedback of traditional teacher. Rollinson (2004) found that teacher is the students' audience and students will write for teacher (not for themselves) when teacher is being traditionally accustomed in giving specific instruction. Recent study was shown that feedback is more useful between drafts, when the feedback done in the end of the task it will make a little improvement. It was shown that in traditional writing class; most of the students are passive.

Nowadays, teacher have to get the students involve in the learning and assessment in ESL/EFL classroom. Teach - centered classroom can be change by encouraging students to participate more actively in the various types of activities. So that the teacher's responsibility in teach - centered classroom can be decreased. To achieve autonomous learning, teacher encourages students to work hand in hand and to take advantage of the implementation of feedback activities and the supervision is under the teacher. Cho and Cho (2011) stated that peer review is a nontraditional form of assessment and its role has been little explored. According to Paulus (1999) in the EFL writing classes, peer reviewis considered to be a significant component of the feedback and revision process. Brown (2001) stated that students will have great experience when they are participating in peer review activities. It enables them to step out of their own selves to see what they 
have created through the eyes of others. There are many advantages of peer review like creating a potentially high level of interaction between readers and writers and it makes teachers more aware (Rollison, 2005), receiving social support from their peers (Zhang, 1995), writing to a real audience (Mangelsdorf, 1992), participating actively in a wider learning community and taking responsibility for editing their written product (Lam, 2010).

Corbin (2010) stated that in recent years, Peer review has been proved as an effective approach to improve the writing skill and since the prevalence of communicative approach; it is increasingly conducted in writing classes. It increases motivation to write, and to learn how to treat writing as a collaborative social activity, (Farrah, 2012). Since the purpose of the English subject at Cendekia Utama Health College is to make the students able to learn and apply the language related to the nursing terminology and according to AIPNI Curriculum of 2015, the objective of English subject in this college covers the ability of understanding, practicing and writing theirnursing care documentation and it has to realize in four skills of English. Therefore, this study was conducted to contribute to the Nursing Students as EFL students in particular and to all EFL students in general.

\subsection{Research Question}

The statements of the problem of this study are as follow;

1. Does peer review technique help nursing students improve their writing skill in writing their "Nursing care documentation"?

2. Does peer review technique increase positive attitudes toward writing among nursing students as EFL students?

\subsection{Objectives of the Study}

Refers to the formulation of the research question, the objectives of the study are as follow;

1. To investigate the possible effectiveness of the peer review technique to increase the quality of nursing students' writing skill in writing their "Nursing care documentation".

2. To see whether this method motivates students to write.

\section{Literature Review}


According to Jalaludin (2011), writing is a system for interpersonal communication using various styles of language. It plays a fundamental role in our personal and professional lives. The approach of writing process has changed the teaching way from students' final products to the process of writing, in this case,peer feedback take an important part in the writing instruction. Nowadays, peer feedback is known as critical technique to improve student's writing but in traditional teaching process teachers are the only one who has high knowledge to provide feedback on the students' writing. The key element of language learning is feedback because it can promote minimal or deep learning. Feedback is information provided by an agent regarding some aspects of one's task performance (Hattie and Timperely, 2007). Narciss (2008) also defines feedback as all post-response information that is provided to a learner to inform the learner on his or her actual state of learning or performance.

Mory (2003) discusses that there are four perspectives how feedback supports learning;

1. It can be considered as an incentive for increasing response rate and/ or accuracy.

2. It can be regarded as a reinforcer that automatically connects responses to prior stimuli (focused on correct responses).

3. It can be considered as information that learners can use to validate or change a previous response (focused on erroneous responses).

4. It can be regarded as the provision of scaffolds to help students construct internal schemata and analysis their learning processes.

Based on several important language learning theories, peer review is including inthe cooperative learning and social interaction. Cooperative learning refers to collaborative learning. Jacobs et al. (1998) stated that cooperative learning can be defined as "the instructional use of small groups so that students work together to maximize their own and each other's learning" (p. 1). Peer review requires students to work together in pairs or small groups depending on the kind of the task students are required to fulfill; therefore, cooperative learning serves as a pedagogical rationale for the use of peer review (or what some may refer to as peer feedback) in ESL writing classes.0'Muirheartaigh (1990) stated that peer review is including the provision of constructive feedback to their peers and 112| ENGLISH EDUCATION 
evaluating and correcting the peer's performances.Peer review can be employed in three forms; pre - peer review, while - peer review and post - peer review;

a. Pre - peer review

In the pre training teacher clarifying the benefits of peer review, grouping the students and keeping foxed ones. Teacher shows how to give feedback/review by doing an example. It can help students to structure their papers more clearly.

b. While - peer review

In this section students begin their peer review and teacher is a monitor.

c. Post - peer review

Students reflect on what they did during peer review and they write about their experience.

Documentation is anything written or electronically generated that describes the status of a client or the care or services given to that client(Perry \& Potter, 2010). Nursing documentation refers to written or electronically generated client information obtained through the nursing process (ARNNL, 2010). Nursing documentation is essential for good clinical communication. Appropriate legible documentation provides an accurate reflection of nursing assessments, changes in conditions, care provided and pertinent patient information to support the multidisciplinary team to deliver great care. Documentation provides evidence of care and is an important professional and medico legal requirement of nursing practice.

Nursing documentation will support the process of;

1. Patient assessment

Assessment is a key component of nursing practice, required for planning and provision of patient and family centred care.

2. Plan of care

A plan of care is a written outline of care for individual clients and is part of the permanent record. The plan of care must be clear to everyone reading the chart. Effective plans of care must be up-to-date and useful to meet the needs and wishes of individual clients. If a standardized plan of care format (e.g., care maps, clinical pathways) is not used, the nurse should ensure that her/his notes identify a plan of care for each assigned client 
3. Real time progress notes

4. Documentation is captured in the patient's progress notes in 'real time' throughout the shift instead of a single entry at the end of shift. Any relevant clinical information is entered in a timely manner such as;

a. Abnormal assessment, eg. Uncontrolled pain, tachycardic, increased WOB, poor perfusion, hypotensive, febrile etc.

b. Change in condition, eg. Patient deterioration, improvements, neurological status, desaturation, etc.

c. Adverse findings or events, eg. IV painful, inflamed or leaking requiring removal, vomiting, rash, incontinence, fall, pressure injury; wound infection, drain losses, electrolyte imbalance, +/-fluid balance etc.

d. Change in plan (Any alterations or omissions from plan of care on patient care plan) eg. Rest in bed, increase fluids, fasting, any clinical investigations (bloods, xray), mobilisation status, medication changes, infusions etc.

e. Patient outcomes after interventions eg. Dressing changes, pain management, mobilisation, hygiene, overall improvements, responses to care etc.

f. Family centred care eg. Parent level of understanding, education outcomes, participation in care, child-family interactions, welfare issues, visiting arrangements etc.

g. Social issues eg. Accommodation, travel, financial, legal etc.

Progress note entries should include nursing content and evidence of critical thinking. That is, they should not simply list tasks or events but provide information about what occurred, consider why and include details of the impact and outcome for the particular patient and family involved. All entries should be accurate and relevant to the individual patient.As cited in the web of the royal children's hospital Melbourne, The structure of each progress note entry should follow the ISBAR philosophy with a focus on the four points of Assessment, Action, Response and Recommendation.

a. Identify reflects to Positive patient identification and ensure details are correct on documents. Write the current date, time and "Nursing" heading. The first entry you make each shift must include your full signature, printed name and designation. Subsequent entries on the same shift must be identified with date/time and 'Nursing' but may be signed only. 
b. Situation \& Background are not often required for 'real-time' entries. It May relevant for admission notes or transfer from one dept to another.

c. Assessment reflects to what does the patient look like? What has happened? Action reflects what have you done about it? Interventions, investigations, change in care or treatment required?

d. Response reflects how has the patient responded? What has changed? Improvement or deterioration?

e. Recommendation reflects what is your recommendation or plan for further interventions or care?

\section{Methods}

\subsection{Participants}

The participants were 78 nursing students in the fourth semester of Cendekia Utama Health College. They were randomly categorized into experimental and control groups.

\subsection{Instrumentation}

\subsubsection{Writing Proficiency Test}

Writing test proficiency was given to the participant to make the comparison between experimental groups and control group homogeneous. They were given two titles from TOEFL test (Sharpe, 2004). One as pre - test and the other one as post - test.

\subsubsection{Peer Response Sheet}

Peer response sheet was given to the experimental group to help the reviewers read their peer work and respond to it. It helps the reviewer focus on their ideas and respond in the best way possible.

\subsubsection{Writing Criteria and Guideline Sheet}

Writing criteria and guidelines sheet were given to both of the group to help them develop their ideas and guide them to write their nursing care documentation correctly.

\subsubsection{Questionnaire}


At the end of the course, a questionnaire were used to see whether peer review technique increase positive attitudes toward writing among nursing students as EFL students. It was translated by using "Likert scale".

\subsection{Procedures}

On the first session, a Pretestof proficiency was given to both experimental and control group, after that both of students groups asked to write their Nursing care documentationwith the same case according to the instruction and writing guidelines and criteria that they had already received. The students in the experimental group were provide with an additional peer review instruction offered by O'Muirheartaigh (1990) including the provision of constructive feedback to their peers and evaluating and correcting the peer's performances. The experiment was run over two month with experimental group receiving peer review while in the control group there only receiving feedback from the teacher. The students were assigned to write about 2 cases of their Nursing care documentationand they were submitting one nursing care documentation in every session.

In the experimental group, they were paired for peer review. They were conferencing and exchanging theirNursing care documentationwith those of their peers. The reviewers had to correct, evaluate and respond those Nursing care documentation. After doing peer review, students meet their peers for peer negotiation and conference that they had already been taught in the peer review instruction session or pre - peer review. After that the reviewers presented their opinion about the problem and mistakes that they had already find and made argument with peer to solve the problem. Reviewers were also asked to write a half page of their feedback. Teacher also gives comment to their nursing care documentation in form of written feedback. After revision sessions, the student revised the Nursing care documentation that implementing the peers' feedback.While, in the control group were traditionally handled by teacher who assigned them homework and correct theirNursing care documentation by themselves. Teacher was giving feedback to their Nursing care documentation in the next session. At the end of the study, the same posttest were given to both groups and corrected by teacher.Students completed survey at the end of the term 
in order to assess the opinion of the student about specific aspects of peer review method. The survey was use questionnaire.

\subsection{Data analysis}

To provide evidence whether any improvement caused by the peer review method in the writing of the experimental group, the data were analyzed and expressed descriptively through 2 experiments.

\section{Result}

\subsection{Normality Test with histogram graphic}

Graphic 1. Histogram of Pre - Test Respondent

The result of normality test of pre - test respondents with histogram graphic shown that the curve of the histogram graphic is symmetric; the data can be measured to the paired t-test.

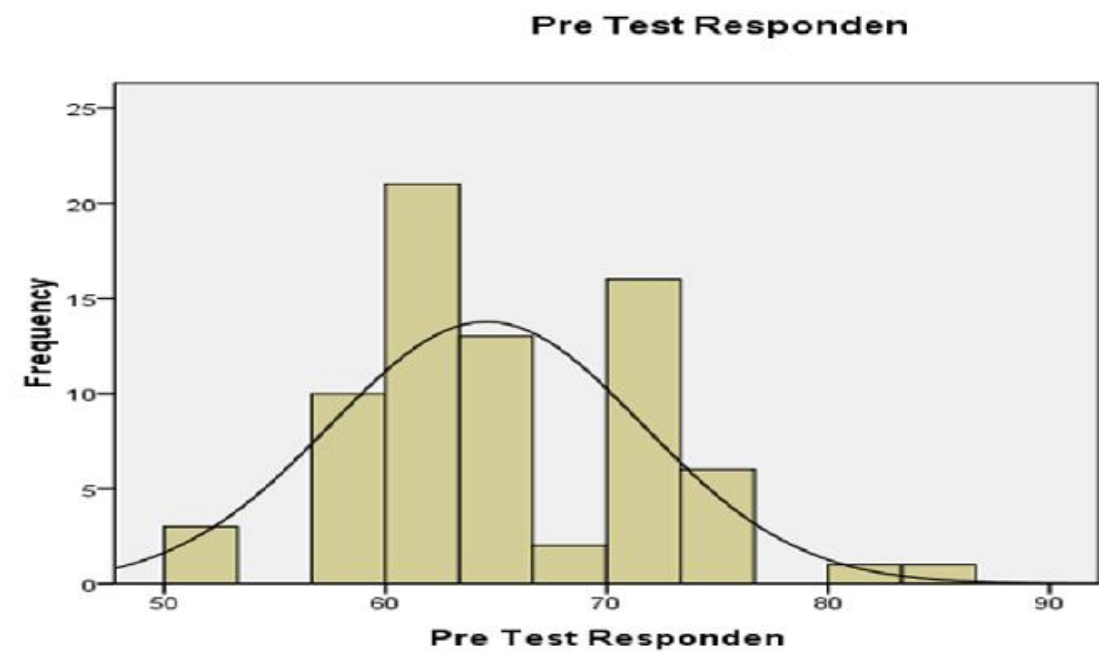

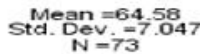

Graphic 1 Histogram of Pre - Test Respondent

Graphic 2. Histogram of Pre - Test Respondent

The normality test of post - test respondents results with histogram graphic shown that the curve of the histogram graphic is symmetric; the data also can be measured to the paired t-test. 


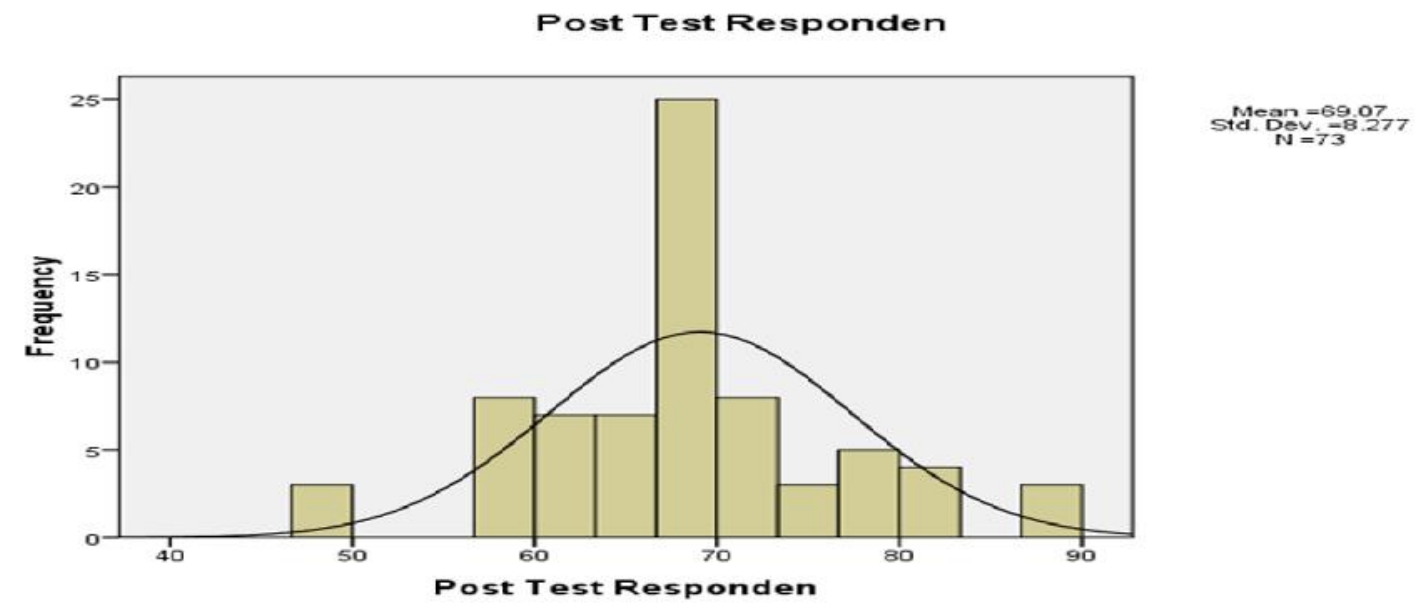

Graphic 2. Histogram of Post - Test Respondent

\subsection{Univariat Analysis}

Table 1 Frequency Table of Pre - Test Respondent indicates that the frequency score of pre - test respondents are $28,8 \%$, the mostly scores are 60 . While in the table 2 indicated that the frequency of post - test respondents are $20,5 \%$, the mostly scores are 68, 5 .

\begin{tabular}{|c|c|c|c|c|c|}
\hline \multicolumn{6}{|c|}{ Pre Test Respondent } \\
\hline & & Frequency & Percent & Valid Percent & $\begin{array}{c}\text { Cumulative } \\
\text { Percent }\end{array}$ \\
\hline \multirow[t]{13}{*}{ Valid } & 50 & 2 & 2.7 & 2.7 & 2.7 \\
\hline & 53 & 1 & 1.4 & 1.4 & 4.1 \\
\hline & 57 & 10 & 13.7 & 13.7 & 17.8 \\
\hline & 60 & 21 & 28.8 & 28.8 & 46.6 \\
\hline & 65 & 11 & 15.1 & 15.1 & 61.6 \\
\hline & 66 & 2 & 2.7 & 2.7 & 64.4 \\
\hline & 67 & 2 & 2.7 & 2.7 & 67.1 \\
\hline & 70 & 11 & 15.1 & 15.1 & 82.2 \\
\hline & 73 & 5 & 6.8 & 6.8 & 89.0 \\
\hline & 75 & 6 & 8.2 & 8.2 & 97.3 \\
\hline & 80 & 1 & 1.4 & 1.4 & 98.6 \\
\hline & 85 & 1 & 1.4 & 1.4 & 100.0 \\
\hline & Total & 73 & 100.0 & 100.0 & \\
\hline
\end{tabular}

\section{8| ENGLISH EDUCATION}




\begin{tabular}{|cc|c|c|c|c|}
\hline \multicolumn{1}{|c|}{} & Frequency & Percent & Valid Percent & $\begin{array}{c}\text { Cumulative } \\
\text { Percent }\end{array}$ \\
\hline Valid & 47 & 1 & 1.4 & 1.4 & 1.4 \\
& 50 & 2 & 2.7 & 2.7 & 4.1 \\
& 57 & 1 & 1.4 & 1.4 & 5.5 \\
60 & 7 & 9.6 & 9.6 & 15.1 \\
63 & 7 & 9.6 & 9.6 & 24.7 \\
65 & 7 & 9.6 & 9.6 & 34.2 \\
67 & 10 & 13.7 & 13.7 & 47.9 \\
70 & 15 & 20.5 & 20.5 & 68.5 \\
73 & 8 & 11.0 & 11.0 & 79.5 \\
75 & 3 & 4.1 & 4.1 & 83.6 \\
80 & 5 & 6.8 & 6.8 & 90.4 \\
83 & 4 & 5.5 & 5.5 & 95.9 \\
87 & 3 & 4.1 & 4.1 & 100.0 \\
Total & 73 & 100.0 & 100.0 & \\
\hline
\end{tabular}

\subsection{Bivariate Analysis}

The result of the bivariate analysis presented in table 5 known that p-score is $0,000<0,05$, So that Ho is Rejected and Ha is Accepted which means there is difference of Pre Test with Post Test score. It is known that statistic $t$ - arithmetic is -6.202 which means the score of pre - test is smaller than post - test with point score 6.202. So the actions given or performed effectively improve the quality or score in the post test. It indicated that the writings of the students in the experimental group improved more than those in control group. Also, those engaged in peer review method were motivated to write more and enjoy writing. It was concluded that peer review provides learners with an authentic audience, increase the students' motivation for writing and enables them to receive different views on their writing. 
T-Test

\begin{tabular}{|ll|c|c|c|c|}
\hline & & Mean & $\mathrm{N}$ & Std. Deviation & Std. Error Mean \\
\hline Pair 1 & Pre Test Responden & 64.58 & 73 & 7.047 & .825 \\
& Post Test Responden & 69.07 & 73 & 8.277 & .969 \\
\hline
\end{tabular}

Table 3 Paired Samples Statistics

\begin{tabular}{|ll|c|c|c|}
\hline & & $\mathrm{N}$ & Correlation & Sig. \\
\hline Pair 1 & $\begin{array}{l}\text { Pre Test Responden\& Post } \\
\text { Test Responden }\end{array}$ & 73 & .685 & .000 \\
\hline
\end{tabular}

Table 4 Paired Samples Correlations

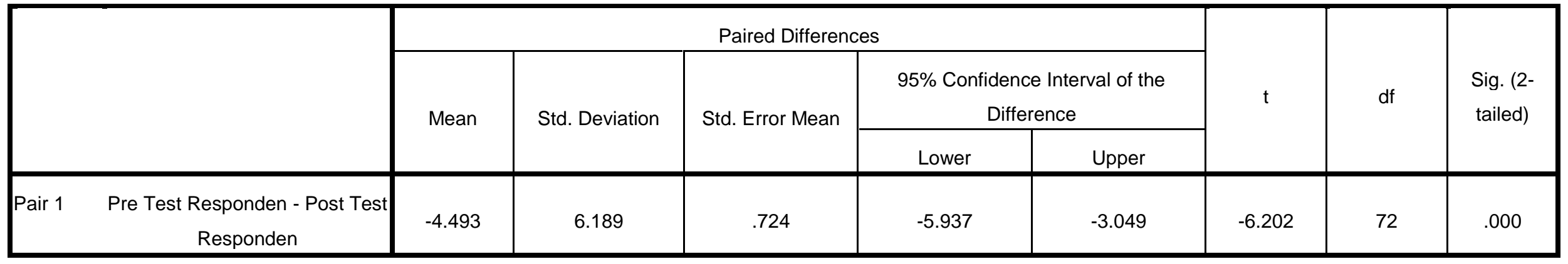

Table 5 Paired Samples Test

120| ENGLISH EDUCATION

Journal of English Teaching and Research 


\section{Discussion And Conclusion}

\subsection{Discussion}

Regarding to the first research question the results shown that in the experimental group who guide by using peer review technique help nursing students improve their writing skill more than in the control group who get the traditional feedback from the teacher in writing their Nursing care documentation. The mean score of Pre - test is 64.58, while post - test score is 69.07. It is known that statistic $t$ arithmetic is -6.202 which means the score of pre - test is smaller than post - test with point score 6.202. So the actions given or performed effectively improve the quality or score in the post test. It indicated that the writings of the students in the experimental group improved more than those in control group.

Also, those engaged in peer review method were motivated to write more and enjoy writing. It was concluded that peer review provides learners with an authentic audience, increase the students' motivation for writing and enables them to receive different views on their writing.

\subsection{Conclusion}

As a conclusion, this study focused on the writing progress and perception of EFL students' through peer review technique. It was found that not only students enjoy the process and product, but also a significant development and change was observed in their writing skill. The peer review process engaged the students in frequent reading and writing and helped them to manage their learning schedule, increased their motivation and joy writing.

\section{References}

ARNNL (Association of Registered Nurses of Newfoundland and Labrador). (2010). Documentation Standards for Registered Nurses. Canada.

Brown, H.D. (2001). Teaching by Principles: An Interactive Approach to Language Pedagogy. (2nd Edition) NY: Longman.

Cho, Y.H. and Cho, K. (2011).Peer Reviewers Learn From Giving Comments, In Instructional Science, 39, 5: 629 - 34.

Corbin, B. (2012). Improving L2 Peer - Feedback.Retrieved From Www.Bryancorbin.Net/2012/Improving-L2-P. 
| Volume: 2 | Number: 2 | October 2017 | E-ISSN: 2503 - 4405 | P-ISSN: 2580-3441|

Dempsey, M. S., Pytlikzilling, L. M., \&Burning, R. H. (2009).Helping Pre - Service Teachers Learn To Asses Writing: Practice And Feedback In A Web - Based Environment. Assessing Writing, 1, 38 - 61.

Farrah, M (2012). The Impact Of Peer Feedback On Improving The Writing Skills Among Hebron University Students. An - Najah Uni. J. Res. (Humanities).

Gao, J. (2004). Teaching Writing InChinese Universities: Finding An Eclectic Approach. Asian EFL Journal, 20 (2), 285 - 297.

Hattie, J., \&Timperley, H. (2007).The Power of Feedback.Review of Educational $\begin{array}{llllll}\text { Research, } & 1 & \text { (77), } & 81 & - & 112 .\end{array}$ Http://Dx.Doi.Org/10.14221/Ajte.2012v37n11.3.

Jacobs, G.M., Curtis, A., Braine, G, \&Huang, S. Y. (1998).Feedback on Student Writing: Taking the Middle Path. Journal of Second Language Writing 7: $307-17$.

Jalaludin, I. (2011). Teacher's Assistance in Developing Rural Learners' Writing Skills and Writing Self - Efficacy: A Case Study. University KebangsanMalaysia.

Kim, Y. And Kim, J. (2005).Teaching Korean University Writing Class: Balancing the Process andthe Genre Approach. Asian EFL Journal 7, (2) 5.

Lam, R. (2010). A Peer Reviews In The ESL Composition Classroom: Coaching Students To Give And Evaluate Peer Feedback, In TESL Canada Journal, 27, 2: $114-27$.

Mangelsdorf, K. (1989). Parallels Between Speaking And Writing In Second Language Acquisition, In D. Jhonson, \&D. Roen(Eds,), Richness In Writing: Empowering ESL Students (Pp. 134 - 135) White Plains, NY: Longman.

Mangelsdorf, K. \&Schlumberger, A. (1992).ESL Student Response Stances In A Peer - Review Task. Journal of Second Language Writing, 1, 235 - 254.

Mory, E. H. (2003).Feedback Research Revisited. In D. H. Jonassen (Ed.), Handbook of Research for Educational Communication and Technology.(PP.745 - 783). New York: Macmillan Library Reference.

Narciss, S. (2008). Feedback Strategies for Interactive Learning Tasks.In J. M. Spector, M.D. 
| Volume: 2 | Number: 2 | October 2017 | E-ISSN: 2503 - 4405 | P-ISSN: 2580-3441|

O’Muircheartaigh, S. (1990). Given Feedback onStudents' Written Work.ELTJ, $44,1-12$.

Paulus, T. (1999).The Effect of Peer and Teacher Feedback on Students Writing.Journal of Second Language Writing, 8 (3), 265 - 289.

Potter, P.A., \& Perry, A.G. (2010).Fundamentals of Nursing. United States of America.

Rollinson, P. (2004) Thinking AboutPeer Review. Oxford University Press.

The Royal Children's Hospital Melbourne. (2017). Retrieved From Http://Www.Rch.Org.Au/Home/

Rollinson, P. (2005). Using Peer Feedback intheESL Writing Class.ELT Journal, $1,23-30$.

Sharpe, P. J. (2004). How To Prepare For The TOEFL Test: Test Of English As A Foreign Language (11th Ed.) New York: Barron's Educational Series.

Zhang, S. (1995).Re - Examining the Effective Advantage of Peer Feedback intheESL Writing Class. 